\title{
Mobile financial services for bottom of pyramid users: Reality or pipe dream?
}

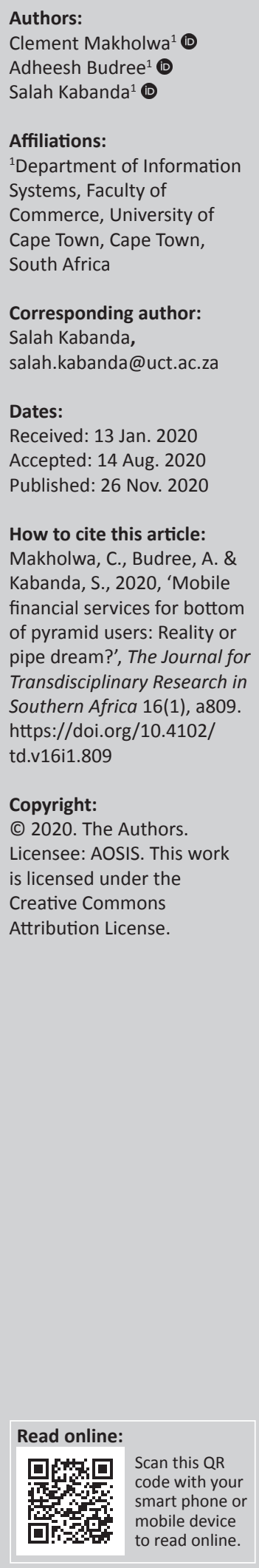

Mobile financial services (MFSs) are perceived to be a potential solution in addressing emerging economies' challenges. Through MFS, benefits associated with economic financial inclusion and economic growth and opportunities could be realised. Yet, not all emerging economies fully experience these benefits, especially in sub-Saharan Africa and more specifically the bottom of the pyramid (BoP) group of individuals who are characterised as the world's poorest consumers, living primarily in the informal sector. This study sought to examine the factors contributing to the BoP group's behavioural intention to adopt MFS in South Africa. The study was positivist in nature, using survey-based questionnaires to garner information from BoP users on MFS adoption. Data were tested for validity and analysed by using structured equation modelling to assess the hypotheses. The findings show that habit, performance expectancy and uncertainty avoidance are strong predictors of behavioural intent. These findings can have significant implications on how MFS service providers operate in the South African context and can be used by government to drive technology as a basis for financial inclusion.

Keywords: Mobile financial services; Bottom of the pyramid; Emerging economies; Financial inclusion; Macro, medium and small enterprises (SMMEs).

\section{Introduction}

Mobile financial services (MFSs) describe a set of mobile-based financial tasks consumers can execute or access by using devices such as cell phones or tablets (Dass \& Pal 2011; Shaikh \& Karjaluoto 2015). With the rapid evolution of technology development today, we see MFS applications or apps increasingly perceived to be a means through which financial inclusion of the unbanked or underbanked people in low-income countries can have access to and become part of greater financial systems (Bourreau \& Valletti 2015). Mobile financial services and related technologies are considered to be an easy, convenient and ideal choice for accessing financial services for those in remote rural areas at lower cost where formal banking is not feasible (Shaikh \& Karjaluoto 2015).

Financial inclusion of the unbanked is generally a well-researched area, partly because of the significant uptake of mobile banking in developing countries. For example, it is estimated that the number of bank accounts is significantly lower than the instance of mobile money accounts across nine African countries thus offering otherwise underbanked or unbanked customers a payment solution (Lowry 2016). The customers targeted by these services are usually the large group of low-income earners living at the bottom of the global economic or wealth pyramid. According to Prahalad and Hart (2002) this group is defined as the bottom of the pyramid (BoP).

The BoP grouping is a socio-economic concept that groups the vast segment of the world's poorest consumers, who live primarily in the informal sector (Prahalad \& Hart 2002) and who live on less than $\$ 2.50 /$ day (Lappeman 2017). Incidence of most of these groups tends to be situated in developing countries and also tends to be unbanked. Prior studies, such as those of Chigada and Hirschfelder (2017), have recorded success stories in the areas of MFS adoption amongst the BoP group in both Kenya and Zimbabwe. Examples of MFS in these countries include M-Pesa in Kenya and EcoCash in Zimbabwe (Mago \& Chitokwindo 2014; Ouma, Odongo \& Were 2017). Whilst most studies focussed on the actual applications that facilitate mobile payments (m-payments) and mobile banking, some recent reports have paid more consideration to the impacts of new technological innovations such as near field communication 
(NFC) within the MFS arena (Chigada \& Hirschfelder 2017; Jenkins \& Ophoff 2016; Richardson \& Callegari 2017; Shaikh, Karjaluoto \& Chinje 2015). Although these studies explain some of the amalgamated factors associated with the adoption of MFS by the BoP group, there have been limited studies within the South African context that explain and provide insights into specific factors that influence BoP group adoption of MFS. The relevance of understanding these factors in the South African context is paramount as the South African BoP market forms approximately 70\% to $75 \%$ of the consumer population, with a high incidence of mobile cellular phone users (Chipp, Corder \& Kapelianis 2013). Based on this gap, the objective of this study is to examine the factors contributing to the BoP group's behavioural intention (BI) to adopt MFS in South Africa. The study uses the unified theory of acceptance and use of technology (UTAUT2) as the initial basis for explaining the intention to use an information system and their ensuing usage behaviour (Venkatesh, Thong \& Xu 2012). The theory is further adapted by including moderating variables of culture from Hofstede's Cultural Dimensions (Hofstede 2010). The rest of the article is arranged as follows: the section 'Literature review' provides related work on MFS and the model development. This is then followed by the section 'Methodology' that details the research methods and techniques employed. The Results section presents the findings of the study and the subsequent section discusses the findings. The final section concludes the study.

\section{Literature review Mobile financial services}

Mobile financial services refer to mobile-based financial services provided through devices such as smartphones or tablets to the unbanked or underbanked to perform financerelated functions (Bourreau \& Valletti 2015). Mobile financial services are categorised into two groups, namely mobile banking ( $m$-banking), a channel that enables a customer to interact with a bank through a mobile device, such as a mobile phone or tablet (Barnes \& Corbitt 2003), and m-payments, conducting payment transactions by using mobile devices to relocate money or funds from a payer to a receiver through a mediating party such as the Global System for Mobile Communications (GSM) network operated by a mobile network operator (Dahlberg et al. 2006). Mobile financial services are increasingly being perceived to be indispensable in emerging economies because of their ability to promote financial inclusion, stimulate economic growth and bring about significant economic opportunities (Dziwornu, Anagba \& Aniapam 2018). With MFSs, users of mobile phones can perform several financial functions such as check account balances, review recent transactions, transfer funds, pay bills, locate ATMs, deposit cheques and manage investments conveniently, quickly and securely from their mobile (Lowry 2016). Rural users can now access low-cost financial services in remote areas where formal banking is deemed not to be feasible (Shaikh \& Karjaluoto 2015). Despite these benefits, and the fact that MFS is seen as a vehicle for achieving poverty reduction and more inclusive economic growth (Demirgüç-Kunt et al. 2015), the level of evolution and uptake has varied by country and this is a concern for countries in the sub-Saharan Africa, which tend to have some of the lowest rates of financial inclusion globally (34\%; Paelo 2017). Previous studies in South Africa have showed that MFS such as M-Pesa have not been successful (Mothobi \& Grzybowski 2017). This has been mainly attributed to, amongst other factors, different market preconditions, poor marketing and distribution (Chigada \& Hirschfelder 2017). Other researchers take the view that this is partly because the Republic of South Africa (RSA) has the most technologically advanced, financially liquid and accessible banking system on the African continent (Rouse 2017), thereby negatively impacting any ideas to transform the traditional banking services into mobile money services that can include all, even the BoP (Chigada \& Hirschfelder 2017). Given that in South Africa alone, incidence of smartphones is now projected at $41 \%$ and is projected to grow by a further 3 million users by 2023 (Statista 2020); it is imperative to understand how those in the BoP perceive MFS and their intentions to adopt MFS.

\section{Factors influencing adoption}

Adoption of technology has traditionally been studied by using one or a combination of the innovation diffusion theory (Rogers 2010), technology acceptance model (Davis 1989; Davis, Bagozzi \& Warshaw 1989), theory of reasoned action (Ajzen \& Fishbein 1980) and the UTAUT (Venkatesh et al. 2012). In this study UTAUT2 is used as a starting point for theorising, mainly because of the nature of its inherent constructs that make it suitable for studying MFS (Hew at al. 2015, Musa, Khan \& AlShare 2015). The constructs associated with UTAUT2 are effort expectancy (EE), facilitating conditions (FCs), habit, hedonic motivation (HM), performance expectancy (PE), price value (PV) and social influence (SI). Performance expectancy refers to one's confidence in the technology's capability to assist in task performance. When particularised to MFS, several studies have reported that PE has a significant direct and indirect effect over the adoption of m-payment (Oliveira et al. 2016) and was perceived as a significant antecedent of usage intention towards m-payment financial services (Lee et al. 2012). The implication is therefore that PE has a positive effect on BI of individuals at the BoP to use m-payments (H1). Effort expectancy is defined as the degree of ease associated with consumers' use of technology' (Venkatesh et al. 2012:159). Nistor et al. (2014) found that EE has a significant effect on BI to use mobile internet services. Similar results are reported by Bankole, Bankole and Brown (2017). From this perspective, EE has the potential to positively affect the BI of individuals at the BoP to use m-payments (H2).

Social influence refers to the social pressure to use a technology. Given that SI can be seen to be meaningfully and positively correlated with intention to use m-payments in South Africa (Killian \& Kabanda 2017), this study hypothesises that SI factors have a positive effect on BI 
of individuals at the BoPs to use m-payments (H3). Facilitating conditions refer to the existence of and the acknowledgement of resource and support available for the usage of the technology (Mahfuz et al. 2016). Using m-payments requires enabling resources and services connected to the Internet such as using a mobile phone or a tablet, which give the ability to download applications, along with knowledge of mobile service networks and privacy and security. A favourable set of FCs will lead to greater intent to use m-payments (Hew et al. 2015). It therefore follows that FCs would have a positive effect on $\mathrm{BI}$ of individuals at the BoPs to use m-payments (H4).

Hedonic motivation is a measure of the pleasure resulting from the use of technology (Brown \& Venkatesh 2005) and has been determined to perform an important role in defining technology acceptance and usage (Yang \& Kim 2012). A recent study in Kenya found that aesthetic and selfgratification values are indicators of customer inclination to pre-adoption choice behaviour to make use of M-Pesa financial offerings (Omigie et al. 2017). On these grounds, this study hypothesises the HM factors that affect BI of individuals at the BoP positively in using m-payments (H5). The PV construct is defined as 'consumers cognitive tradeoffs between the perceived benefits and cost of using various applications' (Venkatesh et al. 2012:161). In the case of m-payments, it may include the subscription fee, transactional fees and data fees together with additional package charges where valid. Therefore, PV has been observed to positively influence usage behaviour when the technology usage benefits are perceived to outweigh the cost (Yang et al. 2012; Wang \& Yi 2012). Prior studies have reported that perceived value influences BI towards m-payment and m-banking applications (Oloko et al. 2014). On these grounds, it is hypothesised that PV has a positive effect on the BI of individuals at the BoP to use m-payments (H6).

Habitual usage or habit reproduces the various outcomes of past experiences (Venkatesh et al. 2012). The consistency of previous behaviour is considered a principal cause of current behaviour (Joosten, Bundy \& Einfeld 2009). Prior studies have shown how habit influenced mobile banking (Baptista \& Oliveira 2015) and BI to use mobile apps (Hew et al. 2015). The study therefore hypothesises that habit has a positive effect on the BI of individuals at the BoP to use m-payments (H7). Behavioural intention has traditionally been seen as the 'sole proximal determinant of IT adoption and use' (Maruping et al. 2017:623). On this note, we hypothesise that BI has a positive effect on usage behaviour of individuals at the BoP to use m-payments $(\mathrm{H} 8)$.

Perceived risk (PR) is understood to be a consumer's individual expectation of suffering a loss in pursuit of a desired outcome (Lee, Warkentin \& Johnston 2016). The role of risk as a stronger predictor of intention to adopt or use mobile transactions has been documented in the past (Chemingui \& Ben lallouna 2013; Di Castri, Grossman \& Sihin 2015; Martins et al. 2014). In this study it is therefore hypothesised that PR has a negative influence on the BI of individuals at the BoP to use m-payments and consequently also on the usage behaviour (H9). Perceived risk has been found to be closely associated with trust, and several studies have established that trust and PR negatively influence each other (Hong 2015; Kim et al. 2009; Liao, Liu \& Chen 2011; Pavlou 2003); whereas others have demonstrated a positive relationship between trust and the decision to use m-banking, m-payments and e-commerce (Masinge 2010). Based on the given discussion, the following hypothesis is deduced: Trust has a positive influence on the $\mathrm{BI}$ individuals at the BoP to use m-payments and consequently also on their usage behaviour (H10).

Khan, Hameed and Khan (2017) identified the cultural constructs of uncertainty avoidance (UA) and collectivism as key moderators in the explanation of online banking $\mathrm{BI}$ and usage behaviour through the examination of online banking technology in the Asian context. According to Hofstede (2010), individualism and/or collectivism (I/C) represents the degree to which individuals are integrated into groups. South Africa within this context is said to have a high score of 65 on individualism, and it is therefore expected that decisions will be taken by users around the technology, whilst in greater collectivist-influenced cultures individuals will base their technology usage decisions of others' opinion (Baptista \& Oliveira 2015). With this understanding, we hypothesise that I/C cultural factors moderate the link amongst usage behaviour and BI such that a stronger relationship will be found where collectivist values are present (H11).

Hofstede (2010) also posited that UA was a key factor to consider when assessing BI and usage behaviour. The realm of the avoidance of uncertainty describes the discomfort felt by members of society when faced with uncertainty and/or ambiguity (Hofstede, 2010). The greater the level of UA, the lower the corresponding technology acceptance rate will be. South Africa scores 49 on this dimension and thus has a low penchant for avoiding uncertainty. It is therefore hypothesised that UA can be used as a moderator for the link between usage behaviour and BIs such that the relationship strength will be diminished in the presence of higher levels of UA (H12). Based on this discussion, Table 1 summarises the identified hypotheses, which influence BIs and usage behaviour and will be used as the basis of investigation for this research.

\section{Methodology Research approach}

This study was driven by a positivism stance and used the hypotheses constructed in Table 1 in the development of a research instrument. The target population was the South African BoP group (who are prone to financial exclusion) identified by residential location, mode of transport they use and job types (Nattrass \& Seekings 2001). Researchers in the developing Fintech landscape have noted that customers who are most likely to download and use m-payments are millennials, macro, medium and small enterprises (SMMEs) 
TABLE 1: Hypothesis development.

\begin{tabular}{|c|c|c|}
\hline UTAUT2 constructs & Hypothesis development & $\begin{array}{l}\text { Source of } \\
\text { questionnaire }\end{array}$ \\
\hline $\begin{array}{l}\text { H1: Performance } \\
\text { expectancy (PE) }\end{array}$ & $\begin{array}{l}\text { Behavioural intention to use m-payments is } \\
\text { positively influenced by PE. }\end{array}$ & $\begin{array}{l}\text { Venkatesh et al. } \\
(2003,2012)\end{array}$ \\
\hline $\begin{array}{l}\text { H2: Effort } \\
\text { expectancy (EE) }\end{array}$ & $\begin{array}{l}\text { Behavioural intention to use m-payments is } \\
\text { positively influenced by effort expectancy. }\end{array}$ & \\
\hline $\begin{array}{l}\text { H3: Social influence } \\
\text { (SI) }\end{array}$ & $\begin{array}{l}\text { Behavioural intention to use m-payments is } \\
\text { positively influenced by social influence. }\end{array}$ & \\
\hline \multirow[t]{2}{*}{$\begin{array}{l}\text { H4: Facilitating } \\
\text { conditions (FC) }\end{array}$} & $\begin{array}{l}\text { a) Behavioural intention to use m-payments is } \\
\text { positively influenced by facilitating conditions. }\end{array}$ & \\
\hline & $\begin{array}{l}\text { b) Use of m-payments is positively influenced } \\
\text { by facilitating conditions. }\end{array}$ & \\
\hline $\begin{array}{l}\text { H5: Hedonic } \\
\text { motivation (HM) }\end{array}$ & $\begin{array}{l}\text { Use of m-payments is positively influenced } \\
\text { by hedonic motivation. }\end{array}$ & \\
\hline H6: Price value (PV) & $\begin{array}{l}\text { Use of m-payments is positively influenced } \\
\text { by PV. }\end{array}$ & \\
\hline \multirow[t]{2}{*}{ H7: Habit (HA) } & $\begin{array}{l}\text { a) Habit has a positive effect on the } \\
\text { behavioural intention to use } m \text {-payments. }\end{array}$ & \\
\hline & $\begin{array}{l}\text { b) Habit has a positive effect on usage } \\
\text { behaviour of m-payments. }\end{array}$ & \\
\hline $\begin{array}{l}\text { H8: Behavioural } \\
\text { intention (BI) and } \\
\text { use behaviour (UB) }\end{array}$ & $\begin{array}{l}\text { Behavioural intent has a positive effect on use } \\
\text { behaviour of } m \text {-payments. }\end{array}$ & \\
\hline \multirow[t]{2}{*}{ H9: Perceived risk } & $\begin{array}{l}\text { a) Behavioural intention to use m-payments } \\
\text { is negatively influenced by perceived risk. }\end{array}$ & $\begin{array}{l}\text { Forsythe et al. } \\
(2006)\end{array}$ \\
\hline & $\begin{array}{l}\text { b) Use of } m \text {-payments is negatively influenced } \\
\text { by perceived risk. }\end{array}$ & \\
\hline \multirow[t]{2}{*}{ H10: Trust } & $\begin{array}{l}\text { a) Behavioural intention to use m-payments } \\
\text { is positively influenced by trust. }\end{array}$ & $\begin{array}{l}\text { Forsythe et al. } \\
(2006)\end{array}$ \\
\hline & $\begin{array}{l}\text { b) Use of m-payments is positively influenced } \\
\text { by trust. }\end{array}$ & \\
\hline $\begin{array}{l}\text { H11: Individualism/ } \\
\text { Collectivism }\end{array}$ & $\begin{array}{l}\text { Individualism/Collectivism (I/C) moderates } \\
\text { between usage behaviour and behavioural } \\
\text { intention such that the relationship strength is } \\
\text { greater in the presence of collectivist values. }\end{array}$ & $\begin{array}{l}\text { Srite and } \\
\text { Karahanna, } \\
\text { (2006); } \\
\text { Hofstede (2010) }\end{array}$ \\
\hline $\begin{array}{l}\text { H12: Uncertainty } \\
\text { avoidance }\end{array}$ & $\begin{array}{l}\text { Uncertainty avoidance (UA) moderates } \\
\text { between usage behaviour and behavioural } \\
\text { intention such that the relationship strength is } \\
\text { weaker in the presence of collectivist values. }\end{array}$ & Hofstede (2010) \\
\hline
\end{tabular}

and the BoP group. These three segments are particularly sensitive to costs and to the improved consumer experience that the MFS delivery and distribution affords them (Dietz, Härle \& Khanna 2016).

\section{Sample and questionnaire}

Researchers in the developing financial technologies landscape have noted that the customers who are most likely to download and use m-payments are millennials, SMMEs and the underbanked. These three segments are particularly sensitive to costs and to the improved consumer experience that the MFS delivery and distribution afford them (Dietz et al. 2016).

To gain a statistical significant sample at a $95 \%$ confidence level, a target of 300 people equitably distributed across the 3 mentioned segments was set (Wagner \& Shimshak 2007). As such, focus was placed on the BoP group as well as millennials who are identified as individuals born from the early 1980s to early 2000s (Howe \& Strauss 2009). The millennials identified were characterised through the presence of BoP group characteristics, specifically the irregular usage of a bank account when monitored on an annual basis, implying a heavier reliance on other financial service providers (Simpson \& Buckland 2009). The sample was from peri-urban dwelling residents in South African townships. These areas, contextually, make it difficult to control activities taking place such as exponential growth of informal settlements, unplanned road infrastructure and uncontrolled traffic circulation, badly located small enterprises and ad hoc distribution of services and infrastructure (Macagnano 2002). Alexandra, Shonganguve, Mamelodi, Mabopane and Middleburg were the townships used in this study. These townships have undergone major changes both in their physical structure and in their administrative reorganisation.

Sampling was conducted randomly, with the first question of the survey testing whether the participant has access to a smartphone device. This eliminated the need for a nonprobability sampling approach as this will regulate eligible respondents and yield a stratified sample. The questionnaire that was applied for the survey questions was based on the hypothesis development of Table 1 and was designed in Microsoft Excel. Two field agents conducted face-to-face interviews with respondents. The data were collected, captured and prepared by using Microsoft Excel and the cleaned raw data were then imported into Statistica and Smart PLS 3 for analysis.

Prior to data collection, permission to conduct the study was requested from the University's ethics committee. Once permission was granted, the objectives, purpose and motivation for this research were explained to all participants, as it was indicated on the cover letter and any questions that they had regarding confidentiality were addressed. Participants were informed prior to commencing with the questionnaire that their participation was voluntary, and they can at any point decide to withdraw their participation for this research. The voluntary nature of the study was also explained to the participants. Respondents were not obliged to complete the entire process if any level of uneasiness arose. Respondents' identities were strictly confidential and remained anonymous throughout the study.

\section{Data collection}

The research instrument made use of a Likert Scale of 5 (strongly agree) to 1 (strongly disagree) linked to the identified hypotheses. Demographic factors of age, race, gender, education and access to smartphones were included. Data collection commenced in June 2018 and was completed in September 2018. All data were collected by using a hardcopy survey because of the consciousness that the respondents are from BoP and are not able to easily access the Internet.

Prior to the survey being conducted, respondents were given a short demonstration of the most popular mobile payments app in South Africa. Respondents were shown the mobile payments app's UI (user interface) and a UX (use experience) demonstration of its functionality. The most inexpensive NFCenabled smartphone currently found in the South African market was used for the demonstration. This demonstrated the minimum system requirements for downloading and using a mobile payments app. This system demonstration helped to inform the respondent of the usability and ease of use of the mobile payments app being used in the survey. 
Two field agents who were former recruitment agents for WIZZIT online bank were contracted to perform the field work. A total of 316 respondents were approached, and the final valid set after exclusions was 311. The data gathered were analysed by using Statistica for the descriptive statistics and to determine the skewness and kurtosis scores. Factor and reliability analyses, as well as a correlation analysis, were conducted. Smart PLS 3 was used for structured equation modelling and factor analysis.

\section{Statistical analysis}

\section{Validity testing}

Discriminant validity and internal reliability were employed to verify the measurement model (Chin 1998). Internal reliability was evaluated by using Cronbach's alpha whilst the composite reliability which is required to have an acceptance level indicator of above 0.70 was calculated by assessing the variation in factor loadings (Hair et al. 2006). Uncertainty avoidance is the only variable that scored lower than the required 0.70 indicator with a value of 0.586 . All other values met the required 0.70 as illustrated in Table 2 . In addition, convergent validity was tested by using average variance extracted (AVE). Convergent validity is suitable when constructs have an AVE of at least 0.50 (Hair et al. 2016). According to Table 2, only 2 out of the 13 constructs presented in the study fell below this value. Habit and UA scored 0.457 and 0.337, respectively, whilst the rest of the constructs' AVE values range from 0.665 to 0.895 .

\section{Skewness and kurtosis analyses}

A key part of statistical analysis is to explain both the location and variability of a data set using normal distribution as a base. This explanation is best done by referring to the skewness and kurtosis of the data set. Skewness measures the symmetry or lack thereof of the distribution of the data. Kurtosis on the other hand measures whether the data are either heavy-tailed (having many outliers) or light-tailed (lacking outliers) relative to a normal distribution. A uniform distribution tends to be a rare occurrence (Heckert et al. 2002). In this study, as shown in Table 3, on an average, the data set

TABLE 2: Internal and External Consistency and Validity Testing.

\begin{tabular}{lcccc}
\hline Constructs & $\begin{array}{c}\text { Cronbach's } \\
\text { Alpha }\end{array}$ & rho_A & $\begin{array}{c}\text { Compositive } \\
\text { Reliability }\end{array}$ & $\begin{array}{c}\text { Average Variance } \\
\text { Extracte }\end{array}$ \\
\hline Behavioural Intention & 0.849 & 0.862 & 0.856 & 0.665 \\
Effort Expectancy & 0.915 & 0.920 & 0.917 & 0.735 \\
Facilitating conditions & 0.884 & 0.910 & 0.890 & 0.675 \\
Habit & 0.779 & 0.834 & 0.753 & 0.457 \\
Hedonic Motivation & 0.948 & 0.948 & 0.948 & 0.859 \\
Individualism/ & 0.853 & 0.892 & 0.869 & 0.632 \\
Collectivism & & & & \\
Perceived Risk & 0.946 & 0.946 & 0.946 & 0.854 \\
Performance Expectancy & 0.941 & 0.942 & 0.941 & 0.801 \\
Price Value & 0.962 & 0.965 & 0.962 & 0.895 \\
Social influence & 0.963 & 0.963 & 0.963 & 0.898 \\
Trust & 0.942 & 0.943 & 0.942 & 0.804 \\
Uncertainty Avoidance & 0.586 & 0.745 & 0.625 & 0.337 \\
Use Behaviour(UB) & 0.892 & 0.905 & 0.892 & 0.678 \\
\hline
\end{tabular}

had few outliers, with kurtosis values closely set around the mean and minimal skewness found.

\section{Structural equation modelling}

The structural equation model was developed to identify the associations between the constructs in the research model (Hair et al. 2016). For this study, the relationship between dependent and independent variables was tested by path coefficients ( $\beta$ ). According to Hair et al. (2016) path coefficients above 0.20 are identified as significant whereas those with values below 0.10 are not usually considered to be significant, provided that values are standardised. The model was found to explain $70.7 \%$ of the variance in BI to use mobile payments (0.707) as shown in Figure 1. The highest correlations can be seen between $\mathrm{BI}$ and EE, FCs, habit, PR, I/C, PE, SI, trust and uncertainty avoidance, as depicted in Table 4.

\section{Ethical considerations}

All ethical conditions were met and approved by the Commerce Faculty Ethics in Research Committee. This was cleared using 2018_ MKHCLE003 as reference number for the study. The objectives, purpose and motivation for this research was explained to all participants as it was indicated on the cover letter and any questions that they had regarding confidentiality were addressed. They were informed prior to commencing with the questionnaire that their participation was voluntary, and they can at any point decide to withdraw their participation for this research.

\section{Results \\ Descriptive statistics}

The survey was conducted in three South African townships over a period of 3 months between June 2018 and September 2018. The results show that $65 \%$ of the total sample identified themselves as male, whilst the remaining 35\% identified themselves as female. Four age brackets were used: 16-24 at $20 \% ; 25-34$ at $41 \% ; 35-50$ at $36 \%$; and lastly 50 and over at $3 \%$, in categorising the sample's age distribution. More than half of the sample (56\%) classified themselves as working and $48 \%$ earning R5000 or more. The majority of the study's sample had some level of education, the largest group of which being 'technical artisan' at $43 \%$, followed by 'some high school or matriculated' at $27 \%$, 'college, university or

TABLE 3: Skewness and kurtosis analyses.

\begin{tabular}{lcc}
\hline Constructs & Kurtosis & Skewness \\
\hline Performance expectancy & 0.44049322 & -0.770435685 \\
Effort expectancy & 0.36242027 & -0.531337904 \\
Social influence & -0.128381048 & -0.516287569 \\
Facilitating conditions & 1.880697516 & -0.766265445 \\
Price value & 1.043190996 & -0.866662052 \\
Hedonic motivation & 0.30219461 & -0.75319896 \\
Habit & -0.123082734 & -0.029468421 \\
Behavioural intention & 1.868081275 & -1.042257597 \\
Trust & 0.727748647 & -0.331415432 \\
Perceived risk & 1.943578166 & -0.745215774 \\
Individualism/collectivism & 1.884126667 & -1.072256357 \\
Uncertainty/avoidance & 0.338636387 & 0.075937542 \\
\hline
\end{tabular}




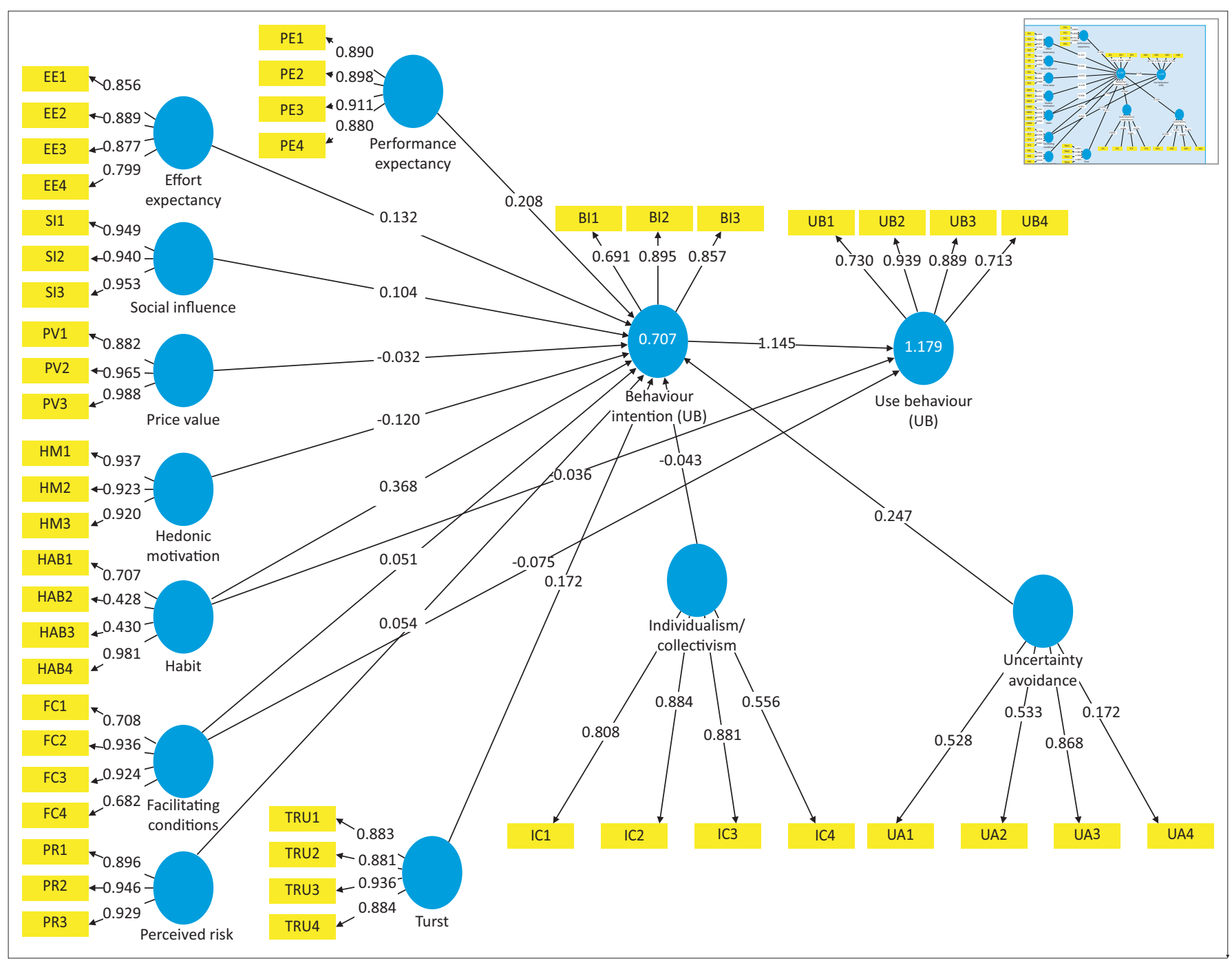

FIGURE 1: Structural equation modelling.

TABLE 4: Correlation analysis.

\begin{tabular}{|c|c|c|c|c|c|c|c|c|c|c|c|c|c|}
\hline \multirow[t]{2}{*}{ Constructs } & \multicolumn{13}{|c|}{ Latent Variable Correlations } \\
\hline & BI & $\mathrm{EE}$ & FC & НАВ & HM & I/C & PR & PE & PV & SI & Trust & U/A & UB \\
\hline Behavioral Intention (BI) & 1.000 & 0.675 & 0.546 & 0.585 & 0.332 & 0.430 & 0.571 & 0.699 & 0.197 & 0.507 & 0.549 & 0.472 & 1.088 \\
\hline Effort Expectancy & 0.675 & 1.000 & 0.629 & 0.407 & 0.271 & 0.471 & 0.498 & 0.808 & 0.192 & 0.512 & 0.488 & 0.339 & 0.638 \\
\hline Facilitating conditions & 0.546 & 0.629 & 1.000 & 0.451 & 0.265 & 0.320 & 0.407 & 0.597 & 0.279 & 0.387 & 0.345 & 0.220 & 0.534 \\
\hline Habit & 0.585 & 0.407 & 0.451 & 1.000 & 0.678 & 0.235 & 0.405 & 0.450 & 0.284 & 0.239 & 0.364 & 0.139 & 0.600 \\
\hline Hedonic Motivation & 0.332 & 0.271 & 0.265 & 0.678 & 1.000 & 0.115 & 0.227 & 0.261 & 0.269 & 0.113 & 0.277 & 0.165 & 0.356 \\
\hline Individualism/Collectivism & 0.430 & 0.471 & 0.320 & 0.235 & 0.115 & 1.000 & 0.334 & 0.420 & 0.152 & 0.482 & 0.331 & 0.449 & 0.373 \\
\hline Performance Expectancy & 0.699 & 0.808 & 0.597 & 0.450 & 0.261 & 0.420 & 0.478 & 1.000 & 0.242 & 0.538 & 0.419 & 0.358 & 0.688 \\
\hline Price Value & 0.197 & 0.192 & 0.279 & 0.284 & 0.269 & 0.152 & 0.179 & 0.242 & 1.000 & 0.126 & 0.214 & 0.059 & 0.173 \\
\hline Social influence & 0.507 & 0.512 & 0.387 & 0.239 & 0.113 & 0.482 & 0.340 & 0.538 & 0.126 & 1.000 & 0.325 & 0.312 & 0.461 \\
\hline Trust & 0.549 & 0.488 & 0.345 & 0.364 & 0.277 & 0.331 & 0.768 & 0.419 & 0.214 & 0.325 & 1.000 & 0.198 & 0.523 \\
\hline Uncertainty Avoidance & 0.472 & 0.339 & 0.220 & 0.139 & 0.165 & 0.449 & 0.237 & 0.358 & 0.059 & 0.312 & 0.198 & 1.000 & 0.439 \\
\hline Use Behaviour (UB) & 1.088 & 0.638 & 0.534 & 0.600 & 0.356 & 0.373 & 0.551 & 0.688 & 0.173 & 0.461 & 0.523 & 0.439 & 1.000 \\
\hline
\end{tabular}

post matric' at $23 \%$, 'no formal education' at $4 \%$ and 'primary school' at $3 \%$.

South Africa displays a relatively high percentage of households with bank accounts, estimated to be between $51 \%$ and $80 \%$ (Chigada \& Hirschfelder 2017). It is therefore no surprise that this study's sample had a $96 \%$ response rate for people with active bank accounts. Most respondents in the sample displayed high willingness to use mobile payments $(95 \%)$

\section{Empirical results}

The study tested the relationship between BI and cultural dimensions of UA and I/C, as well as PR and trust on the willingness to adopt and use MFS within the BoP group. The 
TABLE 5: Hypothesis testing.

\begin{tabular}{|c|c|c|c|c|c|c|}
\hline Hypothesis & Path Coefficients & Coefficients & STDEV & T Statis & $P$ Values & Comments \\
\hline H8 & Behavioral Intention (BI) $\rightarrow$ Use Behaviour (UB) & 1.156 & 0.047 & 24.846 & 0.000 & Accepted \\
\hline $\mathrm{H} 2$ & Effort Expectancy $\rightarrow$ Behavioral Intention (BI) & 0.136 & 0.104 & 1.299 & 0.194 & Accepted \\
\hline $\mathrm{H} 4 \mathrm{a}$ & Facilitating conditions $\rightarrow$ Behavioral Intention (BI) & 0.047 & 0.088 & 0.536 & 0.592 & Rejected \\
\hline $\mathrm{H} 4 \mathrm{~b}$ & Facilitating conditions $\rightarrow$ Use Behaviour (UB) & -0.079 & 0.033 & 2.429 & 0.015 & Rejected \\
\hline $\mathrm{H} 7 \mathrm{a}$ & Habit $\rightarrow$ Behavioral Intention (BI) & 0.377 & 0.106 & 3.561 & 0.000 & Accepted \\
\hline $\mathrm{H} 7 \mathrm{~b}$ & Habit $\rightarrow$ Use Behaviour (UB) & -0.041 & 0.037 & 1.094 & 0.274 & Rejected \\
\hline H5 & Hedonic Motivation $\rightarrow$ Behavioral Intention (BI) & -0.127 & 0.085 & 1.490 & 0.137 & Accepted \\
\hline H11 & Individualism/Collectivism $\rightarrow$ Behavioral Intention (BI) & -0.044 & 0.063 & 0.687 & 0.492 & Inconclusive \\
\hline H9 & Perceived Risk $\rightarrow$ Behavioral Intention (BI) & 0.051 & 0.089 & 0.578 & 0.564 & Rejected \\
\hline $\mathrm{H} 1$ & Performance Expectancy Behavioral Intention (BI) & 0.206 & 0.087 & 2.364 & 0.018 & Accepted \\
\hline H6 & Price Value $\rightarrow$ Behavioral Intention (BI) & -0.033 & 0.046 & 0.715 & 0.475 & Rejected \\
\hline H3 & Social influence $\rightarrow$ Behavioral Intention (BI) & 0.105 & 0.057 & 1.851 & 0.065 & Accepted \\
\hline H10 & Trust $\rightarrow$ Behavioral Intention (BI) & 0.176 & 0.083 & 2.127 & 0.034 & Accepted \\
\hline H12 & Uncertainty Avoidance $\rightarrow$ Behavioral Intention (BI) & 0.252 & 0.076 & 3.298 & 0.001 & Accepted \\
\hline
\end{tabular}

Bootstrap method was used to perform the $t$-statistics and $p$-values to normalise the data. Table 5 highlights the path coefficients and hypothesis test results. The findings demonstrate that PE and EE influence an individual's BI to adopt MFS, with values of $\beta=0.206$ for $P E$ on $B I$ and $\beta=0.136$ for EE on BI, respectively. These findings lead us to accept H1 and $\mathrm{H} 2$ and echo prior studies within the context of South Africa (Killian \& Kabanda 2017). The findings also show a moderate significant impact of hedonic motivation on BIs to adopt MFS and thus H5 is accepted. Respondents in this study perceived habit $(\beta=0.377)$ and trust $(\beta=0.176)$ as factors that impact their intentions to adopt MFS. Hypothesis H7 and H10 are therefore accepted. Finally, a very high significance can be observed between the cultural factor of UA ( $\beta=0.252)$ and BIs to adopt MFS. Such a low score for UA implies that there is a higher propensity of technology adoption. Hypothesis H12 is therefore accepted.

Despite the assumption from previous literature, this study found that SI did not have a significant impact of intention to adopt MFS. The results show a slight significance with BI $(\beta=0.105)$. The same findings are reported regarding FCs with low-income earners placing minimum emphasis on the significance of FCs on BI with $\beta=0.047$. This leads to the rejection of hypothesis $\mathrm{H} 4$. Other hypotheses not supported were PV (H6, with $\beta=0.033)$ and PR (H9 with $\beta=0.051)$. The implications of these findings are that both price and PR did not have any significant impact on BI. Finally, the relationship between the cultural factor of I/C and BIs to adopt MFS was inconclusive. Hypothesis 11 is therefore neither rejected nor accepted.

\section{Discussion of findings}

This study sought to examine the factors contributing to the BoP group's BI to adopt MFS in South Africa. Factors perceived to influence adoption of MFS amongst BoP group include performance and EE, habitual usage, trust and UA. Further, if BoP consumers perceive enjoyment in using MFS they could potentially adopt MFS although this was not a significant factor. Figure 2 shows the summary of the findings of factors perceived to influence adoption.

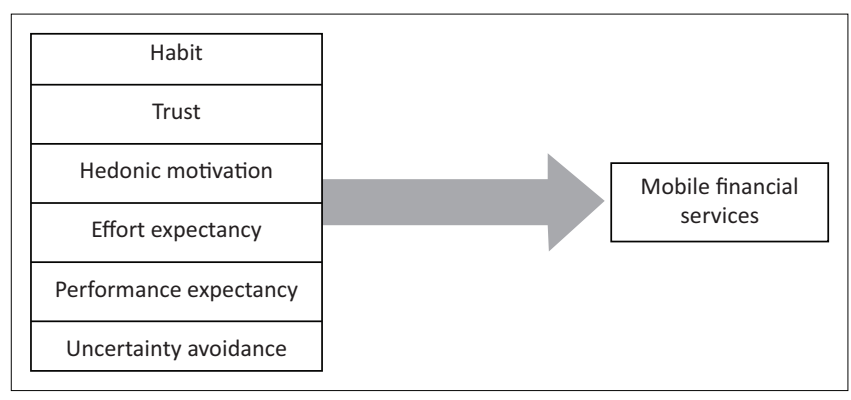

FIGURE 2: Empirical findings of factors influencing bottom of the pyramid's adoption of mobile financial services in South African townships.

Many individuals in South African BoP tend to be dependents because of their low economic and literacy levels and other macroeconomic factors such as high rates of unemployment, male labour migration and premature death brought on by acquired immune deficiency syndrome (AIDS; Schatz, Madhavan \& Williams 2011). For example, in rural communities, people in their early 30s can become financially responsible for parents and siblings (Bidwell et al. 2014). In most cases, these people work in urban areas, sending remittance to their dependents. In this situation, the use of mobile phones as a means of communication has become the norm with BoP members developing a habit of using mobile phones, triggered by situational cues of receiving remittance from and communicating to the providers. This habitual usage of mobile phones impacts self-efficacy, which is highly associated with media consumption such as intention to use mobile phone or internet use (Pourrazavi et al. 2014). This understanding explains why in this study, habitual usage was a significant factor towards MFS adoption. According to Jai and Tung (2015), those consumers who shop online and use mobile services habitually more frequently were more likely to form the habit of using mobile payments. Because habitual usage influenced one's perception of their selfefficacy, there was a strong perception that adoption of MFS would depend on the minimal effort required to use it, if it can be trusted and whether it fulfils the needs of the BoP groups. Mobile financial service was seen to address the needs of BoP individuals because of the ubiquity of the mobile phone, which makes it easier to access finances, perform financial transactions and communicate to their 
significant others (Waema \& Omwansa 2014). Despite an uncertain future, and sub-Saharan African culture being perceived to have UA characteristics (Darley, Luethge \& Blankson 2013), the respondents in this study did not perceive this as a threat towards their intention to adopt MFS. Despite an uncertain future, and sub-Saharan African culture being perceived to have UA characteristics (Darley, Luethge \& Blankson 2013), the respondents in this study did not perceive this as a threat towards their intention to adopt MFS. The implications of these findings show that South African BoP consumers are not constrained by the need to have predictability and stability, but rather are ready to 'accept uncertainty and have greater tolerance for unclear or indefinite situations' (Darley et al. 2013). These characteristics enable South African BoP consumers to be flexible enough to adopt MFS if they perceive that MFS fulfils their needs and are easier to use.

Factors perceived not to impact adoption of MFS were SI, FCs, hedonic value, PR and price value. The BoP group did not perceive being pressured to adopt MFS by their peers or significant other, and the availability of FCs to adopt MFS does not seem to influence their decision to adopt MFS. These findings echo prior studies in similar contexts in South Africa such as San Martín and Herrero (2012) who reported no significant impact of SI and the FCs on online purchase intention. The findings also echo Raleting and Nel (2011) who showed that the availability of FCs significantly influenced ease of use. These findings also suggest that the BoP group does not see high risk involved in the adoption of MFS as there is significant trust in the mobile system, which could be from previous experiences such as purchasing data.

Bottom of pyramid consumers in this context did not see PV as having an impact on their intentions to adopt MFS. This observation can be explained by the fact that 'most mobile users in this country are on prepaid plans, and ... users have developed various strategies to optimise data and data costs, including disconnecting themselves regularly from the mobile Internet' (Mathur, Schlotfeldt \& Chetty 2015) and using short message service (Dalvit, Kromberg \& Miya 2014). With regard to the cultural construct of I/C, the result on the intention to adopt MFS was inconclusive. We therefore cannot conclusively infer that I/C influences BoPs intention to adopt MFS.

\section{Conclusion}

This study's main aim was to understand the factors contributing to the BoP group's BI to adopt MFS in South Africa. Factors perceived to influence adoption of MFS amongst the BoP group include performance and EE, habitual usage, trust, UA and perceived enjoyment. An interesting finding in this study is that the BoP group is very optimistic with regard to how they respond to uncertainty. They have low UA implying that despite the lack of favourable conditions for MFS adoption, the BoP group did not consider these as significant to influence their intention not to adopt
MFS. This observation and the fact that most of these findings resonate with prior studies are an indication that despite the low socio-economic background of the BoP group they are ready to partake in the adoption and use of MFSs. Mobile financial institutions as well as policy interventions from the public sector are therefore encouraged to expand their provision of services to include customers at the BoP.

\section{Limitations}

This study was focussed on the low-income earners' perspective in the South African context. Therefore, the inferences on culture could be different from other countries as well as the large population of immigrants and asylum seekers. In addition, the demographic sample was not fully inclusive in terms of people from other races and geographical locations in South Africa who may be lowincome earners, as the field work was conducted in historical black townships.

\section{Suggestions for future research}

Much research has been conducted in the m-payments and mobile banking space in the past decade. Newer studies could focus on the adoption of MFSs with the expressed intention of solving the issues around the financial inclusion of low-income individuals. A study on the technology readiness of low-income individuals for mobile-driven investments, innovations such as applying the power of the blockchain on traditional community savings schemes and studies on further financial products such as micro-insurance focussed on BoP consumers would add value to the body of knowledge.

\section{Acknowledgements Competing interests}

The authors declare that they have no financial or personal relationships, that may have inappropriately influenced them in writing this research article.

\section{Authors' contributions}

C.M., A.B. and S.K. contributed equally to this research article.

\section{Funding information}

This research received no special grant from any funding agency in the public, commercial or not-for-profit sectors.

\section{Data availability}

Data available from the corresponding author, upon request.

\section{Disclaimer}

The views and opinions expressed in this article are those of the authors and do not necessarily reflect the official policy or position of any affiliated agency of the authors. 


\section{References}

Ajzen, I. \& Fishbein, M., 1980, Understanding attitudes and predicting social behaviour, Prentice-Hall, Englewood Cliffs, N.J.

Bankole, F.O., Bankole, O.O. \& Brown, I., 2017, 'Influences on cell phone banking adoption in South Africa: An updated perspective', Journal of Internet Banking and Commerce 22(3), 1-16.

Barnes, S.J. \& Corbitt, B., 2003, 'Mobile banking: Concept and potential', International Journal of Mobile Communications 1(3), 273-288.

Baptista, G. \& Oliveira, T., 2015, 'Understanding mobile banking: The unified theory of acceptance and use of technology combined with cultural moderators', Computer in Human Behavior 50, 418-430. https://doi.org/10.1016/j.chb.2015.04.024

Bidwell, N.J., Robinson, S., Vartiainen, E., Jones, M., Siya, M.J., Reitmaier, T. et al., 2014, 'Designing social media for community information sharing in rural South Africa', in Proceedings of the Southern African Institute for Computer Scientist and Information Technologists Annual Conference 2014 on SAICSIT 2014 Empowered by Technology, Centurion, South Africa, September, p. 104.

Bourreau, M. \& Valletti, T., 2015, 'Enabling digital financial inclusion through improvements in competition and interoperability: What works and what doesn't', CGD Policy Paper 65, 1-30.

Brown, S.A. \& Venkatesh, V., 2005, 'Model of adoption of technology in households: A baseline model test and extension incorporating household life cycle', MIS Quarterly 29(3), 399-426. https://doi.org/10.2307/25148690

Businesstech, 2019, South Africa's biggest problems - According to South Africans, viewed 16 October 2020, from https://businesstech.co.za/news/business/316944/ south-africas-biggest-problems-according-to-south-africans/.

Chemingui, H. \& Ben Lallouna, H., 2013, 'Resistance, motivations, trust and intention to use mobile financial services', International Journal of Bank Marketing 31(7), 574-592. https://doi.org/10.1108/IJBM-12-2012-0124

Chigada, J.M. \& Hirschfelder, B., 2017, 'Mobile banking in South Africa: A review and directions for future research', South African Journal of Information Management directions for future research', South African Journal of
19(1), 1-9. https://doi.org/10.4102/sajim.v19i1.789

Chin, W.W., 1998, 'The partial least squares approach to structural equation modeling', Modern Methods for Business Research 295(2), 295-336.

Chipp, K., Corder, C. \& Kapelianis, D., 2013, 'The role of collectivism in defining the South African Bottom of the Pyramid', Management Dynamics: Journal of the Southern African Institute for Management Scientists 22(1), 2-13.

Dahlberg, T., Mallat, N., Ondrus, J. \& Bachfischer, A., 2006, Mobile payment market and research-past present and future, Helsinki Mobility Roundtable, Helsinki, Finland, June 1-2, 2006.

Dalvit, L., Kromberg, S. \& Miya, M., 2014, 'The data divide in a South African rural community: A survey of mobile phone use in Keiskammahoek', in Proceedings of the e-Skills for Knowledge Production and Innovation Conference, Informing Science Institute, Cape Town, South Africa, November, pp. 87-100.

Darley, W.K., Luethge, D.J. \& Blankson, C., 2013, 'Culture and international marketing A sub-Saharan African context', Journal of Global Marketing 26(4), 188-202. https://doi.org/10.1080/08911762.2013.814819

Dass, R. \& Pal, S. 2011, 'Exploring the factors affecting the adoption of mobile financial services among the rural under-banked', Proceedings of the 19th European services among the rural under-banked', Proceedings of the $19 t h$
Conference on Information Systems, Helsinki, June 9-11, Paper 246.

Davis, F.D., Bagozzi, R.P. \& Warshaw, P.R., 1989, 'User acceptance of computer technology: A comparison of two theoretical models', Management Science 35(8), 982-1003. https://doi.org/10.1287/mnsc.35.8.982

Davis, F.D., 1989, User acceptance of information systems: The technology acceptance model (TAM), working paper \#529, viewed 16 October 2020, from https://quod.
lib.umich.edu/b/busadwp/images/b/1/4/b1409190.0001.001.pdf, University of Michigan, Ann Arbor, MI.

Demirguc-Kunt, A., Klapper, L., Singer, D, \& Van Oudheusden, P., 2015, The global findex database 2014: Measuring financial inclusion around the world, The World Bank. https://doi.org/10.1596/1813-9450-7255

Di Castri, S., Grossman, J. \& Sihin, R., 2015, Proportional risk-based AML/CFT regimes for mobile money: A framework for assessing risk factors and mitigation measures, viewed 16 October 2020, from https://papers.ssrn.com/sol3/papers.cfm?abstract id $=2928398$.

Dietz, M., Härle, P. \& Khanna, S., 2016, 'A digital crack in banking's business-model', Transactions 577, 483.

Dziwornu, R.K., Anagba, K.K. \& Aniapam, A.D., 2018, 'Emergence of mobile financial services in Ghana: Concerns for use among informal sector women entrepreneurs', Journal of Emerging Market Finance 17(3_Suppl), S415-S432. https://doi. Journal of Emerging Market
org/10.1177/0972652718798191

Forsythe, S., Liu, C., Shannon, D. \& Gardner, L.C., 2006, 'Development of a scale to measure the perceived benefits and risks of online shopping', Journal of Interactive Marketing 20(2), 55-75. https://doi.org/10.1002/dir.20061

Hair, J.F., Black, W.C., Babin, B.J., Anderson, R.E. \& Tatham, R.L., 2006, Multivariate data analysis, vol. 6, Pearson Prentice Hall, Upper Saddle River, NJ.

Hair, J., Hult, G.T.M., Ringle, C., \& Sarstedt, M., 2016, A Primer on Partial Least Squares Structural Equation Modeling (PLS-SEM), 2nd Edn., SAGE Publications, n.I.

Heckert, N.A., Filliben, J.J., Croarkin, C.M., Hembree, B., Guthrie, W.F., Tobias, P. \& Prinz, J., 2002, Handbook 151: NIST/SEMATECH e-Handbook of Statistical Methods, National Institute of Standards and Technology, Maryland, VI.

Hew, J.-J., Lee, V.-H., Ooi, K.-B. \& Wei, J., 2015, 'What catalyses mobile apps usage intention: An empirical analysis', Industrial Management and Data Systems 115(7), 1269-1291. https://doi.org/10.1108/IMDS-01-2015-0028
Hofstede, G., 2010, Geert Hofstede, National Cultural Dimensions, viewed 16 October 2020, from https://scholar.google.com/scholar?hl=en\&as_sdt=0\%2C5\&q=Hofste de\%2C+G.+\%282010\%29.+Geert+hofstede.+National+cultural+dimensions\% de 2 2C+G. +2 . 28 . 2 btnG $=$.

Hong, I.B., 2015, 'Understanding the consumer's online merchant selection process: The roles of product involvement, perceived risk, and trust expectation', International Journal of Information Management 35(3), 322-336.

Howe, N. \& Strauss, W., 2009, Millennials rising: The next great generation, Vintage, New York, NY.

Jai, T.M., \& Tung, T. 2015, 'Fashion innovativeness, information technology innovativeness, and prior experience as factors influencing adoption of apparel mobile E-catalogs', Journal of Global Fashion Marketing 6(3), 163-179.

Jenkins, P. \& Ophoff, J., 2016, 'Factors influencing the intention to adopt NFC mobile payments - A South African perspective', in International Conference on Information Resources Management (CONF-IRM), p. 45.

Joosten, A.V., Bundy, A.C. \& Einfeld, S.L., 2009, 'Intrinsic and extrinsic motivation for stereotypic and repetitive behavior', Journal of Autism and Developmental stereotypic and repetitive behavior', Journal of Autism and Developr
Disorders 39(3), 521-531. https://doi.org/10.1007/s10803-008-0654-7

Khan, I.U., Hameed, Z. \& Khan, S.U., 2017, 'Understanding online banking adoption in a developing country: UTAUT2 with cultural moderators', Journal of Global Information Management (JGIM) 25(1), 43-65. https://doi.org/10.4018/JGIM.2017010103

Killian, D. \& Kabanda, S., 2017, 'Mobile payments in South Africa: Middle income earners' perspective', in Proceedings of the Pacific Asia Conference on Information Systems, Langkawi, Malaysia, July 07, 2017, Paper 53.

Kim, B., 2015, 'The popularity of gamification in the mobile and social era', Library Technology Reports 51(2), 5-9.

Kim, G., Shin, B. \& Lee, H.G., 2009, 'Understanding dynamics between initial trust and usage intentions of mobile banking', Information Systems Journal 19(3), 283-311. usage intentions of mobile banking', Information Syste
https://doi.org/10.1111/j.1365-2575.2007.00269.x

Lappeman, J., 2017, Monthly expenditure category fluctuations and trade-off in South Africa bottom of the pyramid households, University of Cape Town, Cape Town.

Lee, J., Warkentin, M. \& Johnston, A.C., 2016, 'A broader view of perceived risk during Internet transactions', Communications of the Association for Information Systems 38(1), 8, 171-189. https://doi.org/10.17705/1CAIS.03808

Lee, Y.-K., Park, J.-H., Chung, N. \& Blakeney, A., 2012, 'A unified perspective on the factors influencing usage intention toward mobile financial services', Journal of Business Research 65(11), 1590-1599.

Liao, C., Liu, C.C. \& Chen, K., 2011, 'Examining the impact of privacy, trust and risk perceptions beyond monetary transactions: An integrated model', Electronic Commerce Research and Applications 10(6), 702-715.

Lowry, C., 2016, 'What's in your mobile wallet: An analysis of trends in mobile payments and regulation', Federal Communications Law Journal 68(2), 353.

Macagnano, E.V., 2002, 'Peri-urban areas of South African cities: Innovative technologies for sustainability', WIT Transactions on Ecology and the Environment 54, 153-162.

Mago, S. \& Chitokwindo, S., 2014, 'The impact of mobile banking on financial inclusion in Zimbabwe: A case for Masvingo Province', Mediterranean Journal of Socia Sciences 5(9), 221. https://doi.org/10.5901/mjss.2014.v5n20p415

Mahfuz, M.A., Hu, W. \& Khanam, L., 2016, 'The influence of cultural dimensions and website quality on $\mathrm{m}$-banking services adoption in Bangladesh: Applying the UTAUT2 model using PLS', in Wuhan International Conference on e-Business Proceedings, Wuhan, China, 2016, pp. 427-440.

Maruping, L.M., Bala, H., Venkatesh, V. \& Brown, S.A., 2017, ‘Going beyond intention: Integrating behavioral expectation into the unified theory of acceptance and use
of technology', Journal of the Association for Information Science and Technology of technology', Jour
$68(3), 623-637$.

Martins, C., Oliveira, T. \& Popovič, A., 2014, 'Understanding the Internet banking adoption: A unified theory of acceptance and use of technology and perceived adoption: A unified theory of acceptance and use of technology and perceived
risk application', International Journal of Information Management 34(1), 1-13.

Masinge, K., 2010, Factors influencing the adoption of mobile banking services at the Bottom of the Pyramid in South Africa, University of Pretoria, Pretoria.

Mathur, A., Schlotfeldt, B. \& Chetty, M., 2015, 'A mixed-methods study of mobile users' data usage practices in South Africa', in Proceedings of the 2015 ACM International Joint Conference on Pervasive and Ubiquitous Computing, Osaka, Japan, September 7-11, 2015, pp. 1209-1220.

Mothobi, O. \& Grzybowski, L., 2017, 'Infrastructure deficiencies and adoption of mobile money in Sub-Saharan Africa,' Information Economics and Policy 40, 71-79.

Musa, A., Khan, H.U. \& AIShare, K.A., 2015, 'Factors influence consumers' adoption of mobile payment devices in Qatar', International Journal of Mobile Communications mobile payment devices in Qatar', International Journal of Mo
13(6), 670-689. https://doi.org/10.1504/IJMC.2015.072100

Nattrass, N. \& Seekings, J., 2001, “"Two nations"? Race and economic inequality in South Africa today', Daedalus 130(1), 45-70.

News24, 2019, 'SA's biggest challenges in 2019', viewed 16 October 2020, from https://www.news24.com/MyNews24/sas-biggest-challenges-in-2019-20190108.

Nistor, N., Lerche, T., Weinberger, A., Ceobanu, C. \& Heymann, O., 2014, 'Towards the integration of culture into the unified theory of acceptance and use of technology', British Journal of Educational Technology 45(1), 36-55. https://doi.org/10.1111/ j.1467-8535.2012.01383.x

Oliveira, T., Thomas, M., Baptista, G. \& Campos, F., 2016, 'Mobile payment: Understanding the determinants of customer adoption and intention to recommend the technology', Computers in Human Behavior 61, 404-414. https:// doi.org/10.1016/j.chb.2016.03.030

Oloko, M., Anene, E.B., Kiara, P.G., Kathambi, I. \& Mutulu, J., 2014, 'Marketing strategies for profitability: A case of Safaricom Ltd in Kenya Telecommunication Industry', International Journal of Scientific and Research Publications 4(5), 1-5. 
Omigie, N.O., Zo, H., Rho, J.J. \& Ciganek, A.P., 2017, 'Customer pre-adoption choice behavior for M-PESA mobile financial services: Extending the theory of behavior for consumption values', Industrial Management
https://doi.org/10.1108/IMDS-06-2016-0228

Ouma, S.A., Odongo, T.M. \& Were, M., 2017, 'Mobile financial services and financial inclusion: Is it a boon for savings mobilization?', Review of Development Finance 7(1), 29-35. https://doi.org/10.1016/j.rdf.2017.01.001

Paelo, A., 2017, 'A comparison of the mobile financial services sector in Kenya, Tanzania and Uganda', in The 3rd Annual Competition and Economic Regulation (ACER) Conference, Centre for Competition, Regulation and Economic Development (CCRED), Dar es Salaam, 14-15 July 2017, pp. 1-19.

Pavlou, P.A., 2003, 'Consumer acceptance of electronic commerce: Integrating trus and risk with the technology acceptance model', International Journal of Electronic Commerce 7(3), 101-134. https://doi.org/10.1080/10864415.2003.11 044275

Pourrazavi, S., Allahverdipour, H., Jafarabadi, M.A. \& Matlabi, H., 2014, 'A sociocognitive inquiry of excessive mobile phone use', Asian Journal of Psychiatry 10 84-89. https://doi.org/10.1016/j.ajp.2014.02.009

Prahalad, C. \& Hart, S., 2002, 'The fortune at the bottom of the pyramid', in Strategry+Business, viewed 16 October 2020, from https://www.strategybusiness.com/article/11518?_ref=\&pg=all.

Raleting, T. \& Nel, J., 2011, 'Determinants of low-income non-users attitude towards WIG mobile phone banking: Evidence from South Africa', African Journal of Business Management 5(1), 212-223.

Richardson, B. \& Callegari, N., 2017, 'WIZZIT: Prabhu Kandachar and Minna Halme Mobile banking for the poor in South Africa', in P. Kandachar \& M. Halme (eds.), Sustainability challenges and Solutions at the base of the pyramid, pp. 82-91, Sustainability Challenges
Routledge, New York, NY.

Rogers, E.M., 2010, Diffusion of innovations, Simon and Schuster, n.I.

Rouse, M., 2017, 'Mobile banking in Sub-Saharan Africa: Setting the way towards financial development', Munich Personal RePEc Archive, viewed 16 October 2020, from https://mpra.ub.uni-muenchen.de/78006/1/MPRA_paper_78006.pdf.

San Martín, H. \& Herrero, Á., 2012, 'Influence of the user's psychological factors on the online purchase intention in rural tourism: Integrating innovativeness to the UTAUT framework', Tourism Management 33(2), 341-350. https://doi.org/ 10.1016/j.tourman.2011.04.003

Schatz, E., Madhavan, S. \& Williams, J., 2011, 'Female-headed households contending with AIDS-related hardship in rural South Africa', Health and Place 17(2), 598-605. https://doi.org/10.1016/j.healthplace.2010.12.017
Shaikh, A.A. \& Karjaluoto, H., 2015, 'Mobile banking adoption: A literature review', Telematics and Informatics 32(1), 129-142. https://doi.org/10.1016/j. tele.2014.05.003

Shaikh, A.A., Karjaluoto, H. \& Chinje, N.B., 2015, 'Continuous mobile banking usage and relationship commitment - A multi-country assessment', Journal of Financial Services Marketing 20(3), 208-219.

Simpson, W. \& Buckland, J., 2009, 'Examining evidence of financial and credit exclusion in Canada from 1999 to 2005', The Journal of Socio-Economics 38(6), 966-976. https://doi.org/10.1016/j.socec.2009.06.004

Srite, M. \& Karahanna, E., 2006, 'The role of espoused national cultural values in technology acceptance', MIS Quarterly 30(3), 679-704. https://doi.org/10.2307/ 25148745

Statista, 2020, Forecast of smartphone users in South Africa, viewed 16 October, from https://www.statista.com/statistics/488376/forecast-of-smartphone-users-insouth-africa/.

Venkatesh, V., Morris, M.G., Davis, G.B. \& Davis, F.D., 2003, 'User acceptance of information technology: Toward a unified view', MIS Quarterly 27(3), 425-478. information technology: Toward a
https://doi.org/10.2307/30036540

Venkatesh, V., Thong, J.Y. \& Xu, X., 2012, 'Consumer acceptance and use of information technology: Extending the unified theory of acceptance and use of technology', MIS Quarterly 36(1), 157-178. https://doi.org/10.2307/41410412

Waema, T.M. \& Omwansa, T.K., 2014, 'Deepening financial inclusion through collaboration to create innovative and appropriate financial products for the poor', KBA Centre for Research on Financial Markets and Policy, Working Paper Series, Kenya Bankers Association, Nairobi.

Wagner, J.M. \& Shimshak, D.G., 2007, 'Stepwise selection of variables in data envelopment analysis: Procedures and managerial perspectives', European Journal of Operational Research 180(1), 57-67. https://doi.org/10.1016/j. ejor.2006.02.048

Wang, L. \& Yi, Y., 2012, 'The impact of use context on mobile payment acceptance: An empirical study in China', in Advances in computer science and education pp. 293-299, Springer, Berlin.

Yang, S., Lu, Y., Gupta, S., Cao, Y. \& Zhang, R., 2012, 'Mobile payment services adoption across time: An empirical study of the effects of behavioral beliefs, social influences, and personal traits', Computers in Human Behavior 28(1), 129-142. https://doi.org/10.1016/j.chb.2011.08.019

Yang, K. \& Kim, H.Y., 2012, 'Mobile shopping motivation: An application of multiple discriminant analysis', International Journal of Retail \& Distribution Management 40(20), 778-789. 